\title{
Beyond Left and Right: A Scale to Measure Political Ideology in India
}

Running head: Political Ideology in India

Arathy Puthillam ${ }^{1}$, Hansika Kapoor ${ }^{1,2}$, and Sampada Karandikar ${ }^{1}$

${ }^{1}$ Department of Psychology, Monk Prayogshala, Mumbai, India

${ }^{2}$ Neag School of Education, University of Connecticut, CT, USA

\section{Author Note}

Arathy Puthillam ${ }^{3}$ iD https://orcid.org/0000-0003-2426-8362

Hansika Kapoor (D) https://orcid.org/0000-0002-0805-7752

Sampada Karandikar (iD) https://orcid.org/0000-0003-3082-4468

Note that this is only a preprint, in the sense that it has not yet been peer reviewed.

The present study was not funded by any particular grant or organization. Study 1 was presented as a paper at the 2020 Annual Meeting of the International Society of Political Psychology and both the studies were discussed as part of a larger session at the 2021 Virtual Convention of the Society for Personality and Social Psychology

Correspondence concerning this article should be addressed to Arathy Puthillam, Department of Psychology, Monk Prayogshala (Sec 8), 4114, C Wing, Oberoi Garden Estates, Powai, Mumbai 400072, Maharashtra, India.

\footnotetext{
${ }^{3}$ AR, HK, and SSK conceptualized the study, AR, SSK, and HK contributed to data preparation, collection, and analysis. AR and HK contributed to report writing and editing.
} 
E-mail: ar@monkprayogshala.in 


\begin{abstract}
Author CRediT statement
Arathy Puthillam: Conceptualization, Methodology, Data Curation, Formal Analysis, Investigation, Writing- Original Draft Preparation

Hansika Kapoor: Conceptualization, Methodology, Writing- Original Draft Preparation, Review \& Editing
\end{abstract}

Sampada Karandikar: Conceptualization, Methodology, Data Curation

\title{
Acknowledgements
}

We are thankful to Rahul Verma, Deepika Padmanabhan, and Linda J. Skitka for expert opinions and early comments on this project. We are also thankful to Anirudh Tagat and Maitreyee Kishor for their comments on the drafts of this manuscript. 


\begin{abstract}
Most work assessing political ideology and its underpinnings has used primarily western samples. Given India's unique position as the world's largest parliamentary democracy with a multiparty system, the present research aimed to develop a scale to measure political ideology in India. Pilot work indicated that the social and economic bifurcation of the conception of political ideology was inadequate in assessing Indians' stance on political issues. Therefore, in Study 1, 48 items were written relevant to the complex context of political ideology in India. Three factors were extracted based on a sample of 541 Indians $\left(M_{\mathrm{age}}=24.80, S D=8.44\right)$ : purity-based cultural norms, obedience to hierarchy, and economic ideology, highlighting the importance attributed to social concerns. In Study 2, 382 Indians responded to a revised scale $\left(M_{\text {age }}=26.15\right.$ years, $S D=9.00$ ). Based on a confirmatory factor analysis, the three-factor structure was retained. Measurement invariance revealed expected differences between men and women in a few gendered issues such as dowry. Across both studies, economic ideology had poor fit, indicating unreliability of economic issues constituting a consistent ideology in India. Implications, especially with respect to temporal contexts and economic ideology, are discussed.
\end{abstract} Keywords: political conservatism, political ideology in India, scale development, politics in India 


\section{Beyond Left and Right: A Scale to Measure Political Ideology in India}

Over the past 60 years, psychology has increasingly focused on the study of political behaviours. For instance, searching for the term 'political ideology' on Google Scholar yields over a million research items since 2010. The study of political ideology has been interdisciplinary; studies have investigated genetic differences in ideological dispositions(e.g., Hatemi et al., 2014), the role of moral intuitions (e.g., Graham et al., 2011), of the sympathetic nervous system (e.g., Smith \& Warren, 2020), and how ideology translates to political behaviours (e.g., Marcos-Marne et al., 2020).

Political ideology is often thought of as a stable, interdependent system that organizes various social, moral, and economic issues (e.g., Knight, 2006). Ideology has traditionally been conceptualized as falling along the left-right spectrum, based on the French legislative system, where conservatives (monarchists) sat on the right. Consequently, left-wing ideology continues to imply egalitarianism, progressive ideals, and associated social change, whereas right-wing ideology implies veneration of tradition, authority, hierarchy, and the status quo.

Distinction has also been drawn between social and economic issues; social conservatism, for example, is aimed at maintaining traditional social, moral, and religious viewpoints, whereas the involvement of the state in the economy and freedom of private enterprise is the consideration of economic conservatism (Crowson, 2009). Previous work has shown that social and economic ideological positions are relatively distinct; the two have been found to have different psychological correlates and share a low correlation (Crowson, 2009).

Most research on political psychology, however, has also been conducted in the context of the US and Europe (e.g. Jost et al., 2008). In fact, most psychometric tools that assess individual 
differences in political ideology have been framed based on European or American samples (e.g., Everett, 2013). Alternative ways of measuring ideology have used self-identification (e.g., McCright et al., 2016) on a unidimensional spectrum or through party identification (with some parties proxying for liberalism and others for conservatism; e.g., Bullock et al., 2015).

Moreover, Kinder and Kalmoe (2017) have argued that, at least in the context of the US, few understand terminologies such as left- and right-wing or liberal and conservative and few selfidentify as one or the other; most identify as moderate. Further, ideology does not strictly correlate with partisanship, in the sense that even if one identifies with a partisan viewpoint, their personal ideologies do not necessarily align with it. Thus, partisanship-ideology match has been argued to exist only among those who are highly politically knowledgeable and engaged.

This begs the question: how do we delineate the relationship between ideology and everyday politics, given the lack of political sophistication among the majority? That is, if it is difficult for the majority to self-identify as left- or right-leaning, how do we understand how political ideology or partisanship affect our everyday behaviours? Considering the importance of politics in daily life it is necessary to explore its relationship with various psychological outcomes. Consequently, it is vital to have adequate, robust measures of political ideology within different contexts, cognizant of socio-political histories of different countries.

\section{Political Ideology in India}

Considering that India is the world's most populous democracy and is home to a highly diverse population, a scale to measure political ideology in India would be advantageous to further examine political psychology in India. Extant political ideology scales do not concern the unique context of India. For instance, many use the four conflicts relevant to Europe's party systems as a taxonomy: labour vs capital, power concentrations at the federal vs state levels, church vs. the 
state, and cities vs. rural areas (Lipset \& Rokkan, 1967). The socio-political history of India, however, has been organized differently, rooted in the aftermath of British colonialism. The role of political parties and leaders was to create a nation-state with the power to transform society (e.g., Kaviraj, 2010).

Historically, however, transformational powers were not expected of the state; this came to be demanded after independence. As an economically backward country, it was assumed that the state had the responsibility to pull people out of poverty (Chakravarty, 1987), but whether the state should have a role in social change was highly debated; this is generally true in other countries of the postcolonial global south too (Chhibber \& Verma, 2018). This debate further manifested in terms of whether the state should accommodate the interests of various marginalized social groups through political processes, with the premise that equality, especially in a democracy, will not be viable in a country with historical social discrimination. Thus, the need for recognition was required in a "deeply hierarchical society, one in which the state, historically, was the preserve of the upper castes" (Chhibber \& Verma, 2018, p. 34).

Thus, the aforementioned cleavages of European and American politics are fairly distinct from the ones in India. For example, there is no divide in terms of capital and labour in India (Rudolph \& Rudolph, 1987), as seems to be the case in Europe. A majority of the population in India lives in rural areas and work in the unorganized sector; in the organized sector, most trade unions are affiliated with a political party (Mahmood, 2016; Ramaswamy, 1973). Further, there seems to be an alignment in the interests of the state and the capital (Chibber, 2003). Industrialization also was led by the state, with public investment. Majority of the parties also consider the interests of the poor, at least nominally. Thus, the ideological divide in India is unique to its socio-political history. 
Contemporary Indian politics is, however, often viewed as chaotic and revolving around party leaders, given the disintegration of party systems and how, in recent years, politicians have formed and dissolved coalitions (see, for example, Kulkarni, 2019). Additionally, there seems to be consistency in the broad economic structures and policies of the parties that form the government (Nooruddin, 2010; Suri, 2013), with the notable exceptions of the two communist parties (Rodrigues, 2006) and more recently the Hindu nationalist BJP (Malik \& Singh, 1995). The resultant argument, academic and popular, is that Indian politics is non-ideological (e.g., Suri, 2013). The aforementioned partisanship-ideology synthesis, also present in western Europe, might be the cause of such a misperception (Chhibber \& Verma, 2018). Moreover, some have argued that partisan politics is organized based on class and economic conflict in India (Huber \& Inglehart, 1995).

However, politics in India is very much based on ideology. It is not organized based on class or regional differences, as might be the case in other countries, but is based on the role of the state. In fact, social aspects of ideology in multi-ethnic countries like India are generally related to the role of the state, perhaps because the question arises as to which ethnic group controls the state (Chhibber \& Verma, 2018). For instance, social conservatives in India argue that state accommodation should not be extended to caste and religious minorities (Chhibber \& Verma, 2015). Thus, conservative thinking in India dictates that the state should not be burdened with the expectation of transformation, in both, the social and economic domains.

\section{The Multi-Party System in India}

India has thousands of registered political parties, eight of which are national parties, and over 50 are state parties (Election Commission of India, 2020), and there is limited ideological variability within these parties (Suri et al., 2016). This makes it extremely difficult to self-identify 
with respect to political ideology in India. For instance, in 2019, over $29 \%$ of the voters decided their party/candidate of choice either a day or two before, or on the day of the national election (Lokniti Team, 2019); in 2014, over $42 \%$ voted for a party they thought was most likely to win (Lokniti Team, 2014). Thus, there are clear bandwagon effects within voting choice during a national election for a large majority of the population. This is in line with research showing poor political sophistication among the majority in other countries. That is, it has been argued that most political non-elites (i.e., most of the population) are unable to accurately self-identify along the political spectrum (Kinder \& Kalmoe, 2017). Additionally, voting patterns in India seem to differ at a regional level, compared to national elections (Schakel et al., 2019). This might imply a presidentialization of a parliamentary system (Guha, 2018; Wallace, 2019); in other words, citizens are increasingly voting for political personalities at the central (federal) level.

\section{The Present Study}

Extant political ideology scales (e.g., Everett, 2013) focus on their respective countries, the divisive issues of which are not always relevant to India. As discussed, it is also increasingly difficult to assess ideology distinct from partisanship, especially in the Indian context. Accordingly, the present study aimed to develop an Indian political ideology scale. The scale aimed to cover contemporary issues that form the ideological divide in India to assess individual differences in political ideology. In Study 1, we generate items, establish face and content validity, and assess the factor structure, and in Study 2, we confirm the factor structure and check measurement invariance with respect to gender (men and women). 


\section{Method}

\section{Ethics Statement}

The present studies received ethical clearance from the Institutional Review Board at [masked for review] (\#05b-18) in March, 2018.

\section{Study 1}

\section{Item Generation and Selection}

The item pool was generated based on a review of literature on political ideology within the Indian context. For example, in India, abortion is not an ideologically contested issue; however, caste-based discrimination is. Therefore, issues such as positive discrimination (i.e., caste-based affirmative action policies) have been included in the scale. The scale was further modified after consulting with two political scientists with expertise in Indian polity, for content validity. The items were then pilot tested on seven Indians. No items were included or discarded at this point. Finally, a scale consisting of 48 items was administered, out of which 12 broadly represented economic issues, and 36 broadly represented social issues. The asymmetry in the number of items was because the 12 items represented three major economic issues of government interference in the economy, operation of businesses, and taxation. A more diverse array of issues, ranging from homosexuality to acceptance of dowry (see Appendix A) and immigration were included under social issues. This is also in line with previous literature that indicates the lack of variation in economic issues in India across political parties (e.g., Suri, 2013).

\section{Participants and Procedure}

The 48-item measure of political ideology, along with a few demographic details, selfreported political, social, and economic leanings, and political party preferences were included in 
a Google Form. This was then shared with university students in Mumbai. It was also circulated on various social media channels.

A total of 541 participants filled the survey, out of which the data of 514 (women $=307$, Other $=3 ; M_{\text {age }}=24.80, S D=8.44$, range: $\left.18--69\right)$ were retained, based on nationality (not Indian), age (below 18 years), or if they had duplicate responses. About 64\% were students, 34\% were employed, and less than $2 \%$ were unemployed, retired, or on sabbatical.

\section{Results}

Exploratory Factor Analysis (EFA). An initial reliability analysis of all 48 items $(\alpha=$ .91) was conducted to assess whether removing an item would increase the internal consistency of the scale. No items were removed at this stage (Supplementary Table 1).

Parallel analysis and Cattell's scree plot suggested 6 components; a principal axis factor EFA was conducted as a data reduction method. Because the factors were theorized to correlate, the direct oblimin method was used for oblique rotation. Based on the number of items in each component, a four-component model was adopted. All of the items about refugees (see Appendix A) loaded on a single component, and therefore, that component was removed.

The final three-factor model (Table 1) explained $33 \%$ of the variance; the first factor explained $17 \%$ of the variance, the second factor explained $13 \%$, and the third factor explained 3\%. Nine items were removed as they did not contribute to any factor (i.e., loadings below .40) or if there was significant cross-loading with another factor (difference <.20; Table 1). However, five items were retained for economic ideology, even if some had low loadings, to account for the theoretical importance of those items.

The first factor was labelled Purity-based cultural norms (hereon norms). It involved items pertaining to purity-based norms, such as LGBTQ+ rights, religion, dowry, and censorship. 
It included items such as "I don't think people should be allowed to marry outside their religious communities," and "I prefer not associating myself with LGBTQ+ individuals."

The second factor included items related to positive discrimination, traditionalism, and obedience to authority, and therefore was termed Obedience to hierarchical authority (hereon obedience). It included items such as "We should always follow the values of our country" and "I think my country (India) is the best."

The third factor was termed Economic ideology and included items such as "I think the government should control prices of goods and services" and "It is the responsibility of the government to reduce the differences in wealth between the poor and the rich." Two items in this factor with loadings lower than .40 , but higher than .25 were retained, owing to the scant economic-related items in the overall scale.

Intercorrelations and Internal Consistency. The first two factors were positively correlated $(r=.29)$, but both were negatively related to the third factor $(r=-.12$ and $r=-.21$, for Factors 1 and 3, and 2 and 3, respectively). The final scale comprised 34 items. The internal consistency of the entire scale was .89 . The internal consistency of norms (14 items; $M=27.86$, $S D=14.61)$ was .90 , that of obedience ( 15 items; $M=64.70, S D=17.46)$ was .87 , and that of economic ideology (5 items; $M=18.07, S D=4.6$ ) was .45 .

\section{Descriptive statistics, Concurrent Validity, and Group Differences. Descriptive} statistics, zero-order correlations, and correlations with relevant constructs are presented in Table 2. Gender differences (between men and women) and differences between employed participants and students are reported in the Figure and Supplementary Table 2, respectively.

\section{Discussion}


We found that political ideology in India consists of three factors: cultural norms, obedience to authority, and economic beliefs. This is in line with the political thought and state formation in post-independent history of India. For instance, ideological conflicts and debates revolved around the extent to which the nation state should regulate social norms (politics of statism) and whether or not the state should accommodate various historically marginalized groups (politics of recognition; Chhibber \& Verma, 2018). It is also similar to Jaffrelot's (2017) formulation of conservatism in India. Thus, our exploratory analysis is consistent with theoretical formulations of ideology in India.

\section{Study 2}

To confirm the fit of the proposed three-factor model, a confirmatory factor analysis was conducted. Considering the ordinal nature of data, and the non-normal nature of the data, diagonally weighted least squares (WLSMV) was used as the estimator (Li, 2016). Further, to check whether the scale measures ideology similarly across gender, measurement equivalence was conducted for those who self-identified as women and as men. As the number of non-binary individuals were negligible in our sample, measurement equivalence could not ascertained among them.

Next, the effect size of (non)equivalence across the two genders would be tested using $d_{\text {MACS }}$ (Nye \& Drasgow, 2011). These allow us to check the magnitude of non-equivalence at the item-level. Next, item-level differences across the two genders would be assessed using Differential Item Functioning (DIF; Crane et al., 2004). The chi-square criterion, along with an alpha of .001 and a minimum cell size of 5 (i.e., the default) was used.

\section{Participants and Procedure}


The 34-item revised scale, along with a few key demographic details were included in a Qualtrics form. This was shared widely on social media from March to October, 2020.

A total of 382 participants responded to at least $75 \%$ of the scale, out of which 321 (women $=178$, non-binary $=2 ; M_{\text {age }}=26.15$ years, $\mathrm{SD}=9.00$, Range=18-64) participants who responded to each item of the scale were retained. This was because the percentage of responses was significantly related to self-reported interest in politics, thus violating the key assumption of data missing at random. About $46 \%$ were students, $42 \%$ were working, and $11 \%$ were not working.

\section{Results}

Descriptive statistics are presented in Table 3, and participant characteristics are presented in Supplementary Table 3. A Confirmatory Factor Analysis was conducted to test the hypothesized three-factor model, using the 'lavaan' package (Rosseel, 2019), built under R (v. 4.0.2; $\mathrm{R}$ Core Team, 2020). An adequate fit (Hair et al., 2010) was found: $\mathrm{CFI}=.906, \mathrm{TLI}=$ $.899, \mathrm{RMSEA}=.15, \mathrm{SRMR}=.15 ; \chi 2(524)=4226.116, p<.001$.

The item loadings (Panel 1 of Table 4A) were above .33 (i.e., explains at least $10 \%$ of the variance; Brown, 2015) on all items except S19: "lenient on criminals" $(\lambda=.27, \mathrm{SE}=.14$; see Table X), S17: "death penalty" $(\lambda=-.19, \mathrm{SE}=.09), \mathrm{S} 26$ "reservations on economic grounds" $(\lambda$ $=-.21, \mathrm{SE}=.15), \mathrm{S} 27:$ "caste in education" $(\lambda=.16, \mathrm{SE}=.15), \mathrm{E} 44$ "governmental regulations on prices" $(\lambda=.15, \mathrm{SE}=.14), \mathrm{E} 28$ "governmental regulation on large industries" $(\lambda=.27, \mathrm{SE}=$ $.14)$, E42 "reduce wealth differences" $(\lambda=-1.557, \mathrm{SE}=0.132)$, and S38R "rehabilitate criminals" $(\lambda=-0.687, \mathrm{SE}=0.124)$.

Modification indices ( $\mathrm{MI}>.80$; Supplementary Table 4A) indicated that S48 ("National Anthem") loaded on S37 and S17, S19 ("lenient on criminals") loaded on S17, and S17 (“death 
penalty") loaded on S26. Accordingly, S19, S17, and S48 were dropped. This improved the fit of the accompanying model: $\mathrm{CFI}=.947, \mathrm{TLI}=.943, \mathrm{RMSEA}=.12, \mathrm{SRMR}=.12 ; \chi 2(431)=$ $2402.458, p<.001$.

In the modified model (Panel 2 of Table 4A), the item loadings were above .33 on all items except S27: "caste in education" ( $\lambda=.07, \mathrm{SE}=.15)$, S26: "reservations on economic grounds" $(\lambda=-.28, \mathrm{SE}=.15), \mathrm{E} 44$ "governmental regulations on prices" $(\lambda=.18, \mathrm{SE}=.14)$, E28 "governmental regulation on large industries" $(\lambda=.27, \mathrm{SE}=.14), \mathrm{E} 42$ "reduce wealth differences" $(\lambda=-1.6, \mathrm{SE}=.0 .134)$, and E38R "rehabilitate criminals" $(\lambda=-0.677, \mathrm{SE}=0.126)$. However, owing to the theoretical importance of these constructs for economic ideology, none of these were dropped.

The internal consistency of norms was .97 , that of hierarchies was .85 , and of economic ideology was .38. Factor correlations are presented in Table 4B. It is noteworthy that the economic ideology had poor internal consistency.

Measurement invariance for men and women

Gender-based measurement invariance was calculated (Table 5A). Considering the number of individuals identifying outside the gender binary were low $(n=2)$, invariance was evaluated only for men and women. Configural model did not have an acceptable fit (CFI $=.83$, RMSEA $=.09)$, and metric invariance was not met $(\Delta \chi 2(28)=76.826, p<.001, \Delta \mathrm{CFI}=.006$, $\triangle \mathrm{RMSEA}=.00)$.

Next, to facilitate $d$ MACS (Table 5B) and DIF calculations, each subscale was analysed. $d$ MACS was estimated using the "dmacs" package (Dueber \& Zhou, 2019) in R using men as the reference group. The first factor (norms) had a good fit (Supplementary Table 4A). The configural model of Factor 1 had a good fit (Table 5A), but metric invariance was not met. The 
$d$ MACS (Table 5B) in most items were negligible, except S7 ("associate with LGBTQ+ individuals"; $d=.27$ ). The largest changes to mean were associated with S3 ("LGBTQ+ marry"; $\Delta=.31$ ), S25 (“dowry"; $\Delta=.34$ ), S11 (“dowry is inheritance"; $\Delta=.36$ ).

The second factor also had a good fit (Table 5A). The configural model had a poor fit, and metric invariance was not met. The $d \mathrm{MACS}$ for most items were negligible to small, except S27 ("caste in education"; $\mathrm{d}=.40$ ), S22 ("support leaders"; $\mathrm{d}=.33$ ), S23("no divorce"; $\mathrm{d}=.30$ ), S6 ("no refugees"; $\Delta=.32$ ). The largest changes to mean were associated with $\mathrm{S} 27(\Delta=.65)$, S23 $(\Delta=.51)$, S26 "economic reservations" $(\Delta=.51)$, and S45 "law" $(\Delta=.45)$.

The third factor also had a good fit. Measurement invariance were met at all levels (see Table 5A). The $d \mathrm{MACS}$ for all items were negligible; the largest difference in means was due to E38 ("rehabilitate criminals").

Differential Item Functioning (DIF) was assessed for each subscale using the "lordif" package (Choi et al., 2011) in R. Only S7 had DIF among men and women across all items in the scale.

\section{Discussion}

The confirmatory analysis substantiates the claim that political ideology in India has three dimensions. We also found that all three factors are comparatively independent, and had good fit independently as well.

At the item-level, responses to criminal behaviours, national anthem, and positive discrimination had poor loadings. The issues of the national anthem and leniency for criminals were divisive issues when item statements were being drafted. However, during the collection of the confirmatory data, many news stories revolved around custodial deaths and other cases of police violence in India (Karthik K. R. \& Karunanithi, 2020) and around the world (Porterfield, 
2020). Further, the issue of playing national anthem had not been popularly debated during the lockdown period, considering that cinemas were shut throughout the period of data collection. This demonstrates that while utilizing scales measuring ideology, one should be cognizant of the temporal context.

Next, the construct of caste-based reservations poorly fit in with the model. This might be because of the overarching negative attitude that many dominant caste Indians might have about positive discrimination (e.g., Coffey et al., 2018). Only about $13.39 \%$ of our sample selfidentified as belonging to marginalized or backward castes (e.g., Dalit), whereas $61 \%$ selfidentified as belonging to the dominant caste, which might have affected the loadings of these items.

With respect to equivalence across the two genders with a large enough sample, we found that LGBTQ+ rights, the sanctity of marriage, and daughters' inheritance had the largest discrepancies. It is likely that there are gender differences in latent attitudes towards those identifying as LGBTQ+, and sanctity of marriage. For example, men and women usually have different perspectives towards the sanctity of marriage, considering differing implications of the same for both groups. This may be because of a number of reasons, such as women's families being ostracized if she refuses an arranged marriage (Chowdhry, 2004), or women experiencing more social stigma in the face of a divorce, compared to men (Kaneez, 2015).

\section{General Discussion}

The present study aimed to develop a measure of political ideology within the Indian context. This is an essential first step in assessing psychological bases of politics in India. For this, items that assessed a number of ideologically divisive themes in the context were written 
and validated. Next, an exploratory factor analysis was conducted, followed by a confirmatory factor analysis on a second sample. We found that Indian political ideology may be falling along three fairly independent factors: cultural norms, obedience to hierarchical authorities, and the role of the state in the economy.

So far, Indians have been thought to vote based on their social identities. For instance, voting patterns often change based on the election level: people sometimes vote differently based on whether the election is a national versus a local or state-level one (Schakel et al., 2019). This might be because of a number of reasons, including that a regional-level party may not have an equivalent at the national level. This has often been given as evidence for non-ideological voting patterns. However, this has changed in recent years, given the mass popularity of the current Prime Minister, Narendra Modi. That is, more recently, people have been voting for political personalities, rather than parties (Wallace, 2019). This has also led to a more highly centralized power and dilution of regional parties (Aiyar \& Sircar, 2020).

However, there is increasing evidence that ideology too plays a role in voting (Chhibber \& Verma, 2018). For instance, the popularity of the current Prime Minister may be attributable to his evident ideological stance on a number of issues and the ideological shift of the median voter (e.g., Palshikar, 2019). However, this scale does not attempt to measure or predict voting behaviour.

The present study empirically supports previously theorized ideological cleavages specific to India (Chhibber \& Verma, 2018; Jaffrelot, 2017). In other words, our study supports their contention that Indian political ideology comprises three latent factors: social norms, which measures the statist belief about social and cultural norms; obedience to hierarchical structures, which measures politics of recognition, and economic ideology. 
However, men and women have different interpretations of some issues. For instance, men and women interpreted the item on associating with LGBT+ individuals differently. Previous studies have found that women hold more favourable attitudes towards homosexuality (Ahuja, 2017). Future research should attempt to understand why this might be the case. Further, previous studies have not explored attitudes towards bi/pansexuality or trans/non-binary individuals.

Finally, some temporal differences were found in endorsed attitudes towards certain issues. This is to be expected, based on the contested issues in news and other media (Choma et al., 2018). For instance, the second (i.e., confirmatory) study was conducted during a time where police brutality was discussed both globally and in India (Karthik K. R. \& Karunanithi, 2020; Porterfield, 2020).

Economic ideology was found to not be an important factor in political ideology in India. In the present scale, however, we have not deleted the items pertaining to this factor. This is because at the level of individual differences, it is likely that there might be a more coherent ideology for that factor. Further, it is also likely that there might be differences between political elites (including, for example, students and practitioners of economics and policy) and non-elites within this factor. Thus, we propose that those using this scale for their work discard the scale based on their sample target in future studies. For instance, this scale may be of interest to those studying individual differences in political ideology among self-identified libertarians, but perhaps not to those studying ideological correlates of collective narcissism in India.

\section{Limitations and Conclusion}

In attempting to create a scale to measure political ideology in India, this study is, to the best of our knowledge, the first to empirically study ideology in India in a methodologically 
rigorous manner. However, it is not without limitations. First, this study was conducted in English. Future research should attempt to translate the scale to regional languages. This, however, might be problematic considering that regional languages are not geographically diverse. For instance, if the scale is translated to Hindi, only those from northern and central regions of India would be adequately represented. Next, a large enough number of gender nonbinary/ non-conforming people were not represented. This is essential considering the weightage LGBT+ issues had in our political ideology scale. Further, clubbing LGBT+ issues together also comes with a number of problems. However, given the expanse of issues considered, this was the most frugal. The confirmatory study was overly representative of dominant caste Hindu individuals, despite our best attempts to be representative of other castes. Future research should aim to bridge this gap by sampling specific population groups.

In sum, we developed a psychometric instrument to measure political ideology in India using data from two investigations. Two important sub-facets of ideology were identified: social and cultural norms and obedience to hierarchical authority. The third sub-facet of economic ideology was found to not be an important factor in India. Future work will need to consider whether and how economic ideology applies to the Indian context, as well as investigate behavioural correlates and other individual differences associated with Indian political ideology. 


\section{References}

Ahuja, K. K. (2017). Development of Attitudes Toward Homosexuality Scale for Indians (AHSI). Journal of Homosexuality, 64(14), 1978-1992. https://doi.org/10.1080/00918369.2017.1289006

Aiyar, Y., \& Sircar, N. (2020). Understanding the decline of regional party power in the 2019 national election and beyond. Contemporary South Asia, 1-14. https://doi.org/10.1080/09584935.2020.1765989

Banerjee, P. R. (2014). Dowry in 21st-Century India: The Sociocultural Face of Exploitation. Trauma, Violence, \& Abuse, 15(1), 34-40. https://doi.org/10.1177/1524838013496334

Bhalotra, S., Chakravarty, A., \& Gulesci, S. (2020). The price of gold: Dowry and death in India. Journal of Development Economics, 143, 102413. https://doi.org/10.1016/j.jdeveco.2019.102413

Brown, T. A. (2015). Confirmatory factor analysis for applied research. Guilford publications.

Bullock, J. G., Gerber, A. S., Hill, S. J., \& Huber, G. A. (2015). Partisan Bias in Factual Beliefs about Politics. Quarterly Journal of Political Science, 10(4), 519-578. https://doi.org/10.1561/100.00014074

Chakravarty, S. (1987). The State of Development Economics. The Manchester School, 55(2), 125-143. https://doi.org/10.1111/j.1467-9957.1987.tb01293.x

Chhibber, P. K., \& Verma, R. (2015). The BJP's 2014 “Modi Wave": An Ideological Consolidation of the Right. Economic and Political Weekly, 49(39), 7-8. 
Chhibber, P. K., \& Verma, R. (2018). Ideology and identity: The changing party systems of India. Oxford University Press.

Chibber, V. (2003). Locked in place: State-building and late industrialization in India. Princeton University Press.

Choi, S. W., Gibbons, L. E., \& Crane, P. K. (2011). Lordif: An R package for detecting differential item functioning using iterative hybrid ordinal logistic regression/item response theory and Monte Carlo simulations. Journal of Statistical Software, 39(8), 1.

Choma, B. L., Jagayat, A., Hodson, G., \& Turner, R. (2018). Prejudice in the wake of terrorism: The role of temporal distance, ideology, and intergroup emotions. Personality and Individual Differences, 123, 65-75. https://doi.org/10.1016/j.paid.2017.11.002

Chowdhry, P. (2004). Caste panchayats and the policing of marriage in Haryana: Enforcing kinship and territorial exogamy—Prem Chowdhry, 2004. Contributions to Indian Sociology, 38(1-2), 1-42. https://doi.org/10.1177/006996670403800102

Coffey, D., Hathi, P., Khurana, N., \& Thorat, A. (2018). Explicit Prejudice: Evidence from a new survey. Economic and Political Weekly, 53(1), 7-8.

Crane, P. K., Belle, G. van, \& Larson, E. B. (2004). Test bias in a cognitive test: Differential item functioning in the CASI. Statistics in Medicine, 23(2), 241-256. https://doi.org/10.1002/sim.1713

Crowson, H. M. (2009). Are all conservatives alike? A study of the psychological correlates of cultural and economic conservatism. The Journal of Psychology, 143(5), 449-463. https://doi.org/10.3200/JRL.143.5.449-463 
Dueber, D., \& Zhou, H. (2019). Dmacs. https://cran.r-project.org/package=dmacs

Election Commission of India. (2020). Amending Notification regarding Political Parties and their Symbol dated 30.09.2020. Election Commission of India. https://eci.gov.in/files/file/12307-amending-notification-regarding-political-parties-andtheir-symbol-dated-30092020/

Everett, J. A. (2013). The 12 item social and economic conservatism scale (SECS). PloS One, 8(12), e82131. http://www.doi.org/10.1371/journal.pone.0082131

Graham, J., Nosek, B. A., Haidt, J., Iyer, R., Koleva, S., \& Ditto, P. H. (2011). Mapping the moral domain. Journal of Personality and Social Psychology, 101(2), 366. https://doi.org/10.1037/a0021847

Guha, K. (2018, December 28). 2019 polls: By making it Modi vs Rahul, media has created a narrative that benefits only the PM. Scroll.In. https://scroll.in/article/906994/2019-polls-bymaking-it-modi-versus-rahul-media-has-created-a-narrative-that-benefits-only-the-pm

Hair, J. F., Black, W. C., Babin, B. J., \& Anderson, R. E. (2010). Multivariate data analysis: International version. New Jersey, Pearson.

Hatemi, P. K., Medland, S. E., Klemmensen, R., Oskarsson, S., Littvay, L., Dawes, C. T., Verhulst, B., McDermott, R., Nørgaard, A. S., \& Klofstad, C. A. (2014). Genetic influences on political ideologies: Twin analyses of 19 measures of political ideologies from five democracies and genome-wide findings from three populations. Behavior Genetics, 44(3), 282-294. https://doi.org/10.1007/s10519-014-9648-8 
Huber, J., \& Inglehart, R. (1995). Expert interpretations of party space and party locations in 42 societies. Party Politics, 1(1), 73-111. https://doi.org/10.1177/1354068895001001004

Jaffrelot, C. (2017). The Roots and Varieties of Political Conservatism in India. Studies in Indian Politics, 5(2), 205-217. https://doi.org/10.1177/2321023017727968

Jost, J. T., Nosek, B. A., \& Gosling, S. D. (2008). Ideology: Its resurgence in social, personality, and political psychology. Perspectives on Psychological Science, 3(2), 126-136. https://doi.org/10.1111/j.1745-6916.2008.00070.x

Kaneez, S. (2015). Perception of Subjective Well-being among Divorced Women: A Comparative Study of Hindus and Muslims. Pakistan Journal of Social and Clinical Psychology, 13(2), 67-71.

Karthik K. R., V., \& Karunanithi, J. (2020, 17). Tamil Nadu Custodial Deaths Are a Reminder Not to Miss the Forest for the Trees. The Wire. https://thewire.in/rights/tamil-naducustodial-deaths-are-a-reminder-not-to-miss-the-forest-for-the-trees

Kaviraj, S. (2010). The imaginary institution of India: Politics and ideas. Columbia University Press.

Kinder, D. R., \& Kalmoe, N. P. (2017). Neither liberal nor conservative: Ideological innocence in the American public. University of Chicago Press.

Knight, K. (2006). Transformations of the Concept of Ideology in the Twentieth Century. American Political Science Review, 619-626. https://doi.org/10.1017/S0003055406062502

Kulkarni, D. (2019). Maharashtra Assembly Elections 2019: Local versus 'National’ Issues. Economic and Political Weekly, 54(44), 7-8. 
Li, C.-H. (2016). Confirmatory factor analysis with ordinal data: Comparing robust maximum likelihood and diagonally weighted least squares. Behavior Research Methods, 48(3), 936949. https://doi.org/10.3758/s13428-015-0619-7

Lipset, S. M., \& Rokkan, S. (1967). Cleavage structures, party systems, and voter alignments: An introduction. Free Press New York.

Lokniti Team. (2014). NES-Postpoll 2014-Findings(Weight by state proportion and Actual Vote share). Lokniti-CSDS.

Lokniti Team. (2019). All India Postpoll NES 2019-Survey Findings. Lokniti-CSDS.

Mahmood, Z. (2016). Trade Unions, Politics \& Reform in India. Indian Journal of Industrial Relations, 51(4), 531-549.

Malik, Y. K., \& Singh, V. B. (1995). Hindu nationalists in India: The rise of the Bharatiya Janata Party. Vistaar Publ.

Marcos-Marne, H., Plaza-Colodro, C., \& Freyburg, T. (2020). Who votes for new parties? Economic voting, political ideology and populist attitudes. West European Politics, 43(1), 1-21. https://doi.org/10.1080/01402382.2019.1608752

McCright, A. M., Dunlap, R. E., \& Marquart-Pyatt, S. T. (2016). Political ideology and views about climate change in the European Union. Environmental Politics, 25(2), 338-358. https://doi.org/10.1080/09644016.2015.1090371

Nooruddin, I. (2010). Coalition politics and economic development: Credibility and the strength of weak governments. Cambridge University Press. 
Nye, C. D., \& Drasgow, F. (2011). Effect Size Indices for Analyses of Measurement Equivalence: Understanding the Practical Importance of Differences Between Groups. Journal of Applied Psychology, 96(5), 966-980. https://doi.org/10.1037/a0022955

Palshikar, S. (2019, June 26). People's demand for a strong leader feeds into the BJP's majoritarian politics perfectly. The Indian Express. https://indianexpress.com/article/opinion/columns/narendra-modi-bjp-congress-rahulgandhi-leadership-5799770/

Porterfield, C. (2020, 30). Global Protests Sparked By George Floyd's Death Spread To Toronto, London And Berlin. Forbes. https://www.forbes.com/sites/carlieporterfield/2020/05/30/global-protests-sparked-bygeorge-floyds-death-spread-to-toronto-london-and-berlin/

R Core Team. (2020). R: A Language and Environment for Statistical Computing [R]. R Foundation for Statistical Computing. https://www.R-project.org/

Ramaswamy, E. A. (1973). Politics and Organized Labor in India. Asian Survey, 13(10), 914928. https://doi.org/10.2307/2643002

Rodrigues, V. (2006). The communist parties in India. In India's Political Parties (pp. 199-252). Sage Publications Pvt. Limited.

Rosseel, Y. (2019). Lavaan (0.6-5) [Computer software].

Rudolph, L. I., \& Rudolph, S. H. (1987). In pursuit of Lakshmi: The political economy of the Indian state. University of Chicago Press. 
Schakel, A. H., Sharma, C. K., \& Swenden, W. (2019). India after the 2014 general elections: BJP dominance and the crisis of the third party system. Regional \& Federal Studies, 29(3), 329-354. https://doi.org/10.1080/13597566.2019.1614921

Smith, K. B., \& Warren, C. (2020). Physiology predicts ideology. Or does it? The current state of political psychophysiology research. Current Opinion in Behavioral Sciences, 34, 88-93. https://doi.org/10.1016/j.cobeha.2020.01.001

Suri, K. (2013). Party system and party politics in India. In Political Science: Volume 2: Indian Democracy (Vol. 2, pp. 209-252). Oxford University Press.

Suri, K., Elliott, C., \& Hundt, D. (2016). Democracy, governance and political parties in India: An introduction. Studies in Indian Politics, 4(1), 1-7. https://doi.org/10.1177/2321023016634902

Wallace, P. (2019). India's 2019 Elections: The Hindutva Wave and Indian Nationalism. Sage Publications Pvt. Limited. 
Figure 1

Figure 1: Gender differences in the total scale and its subfactors

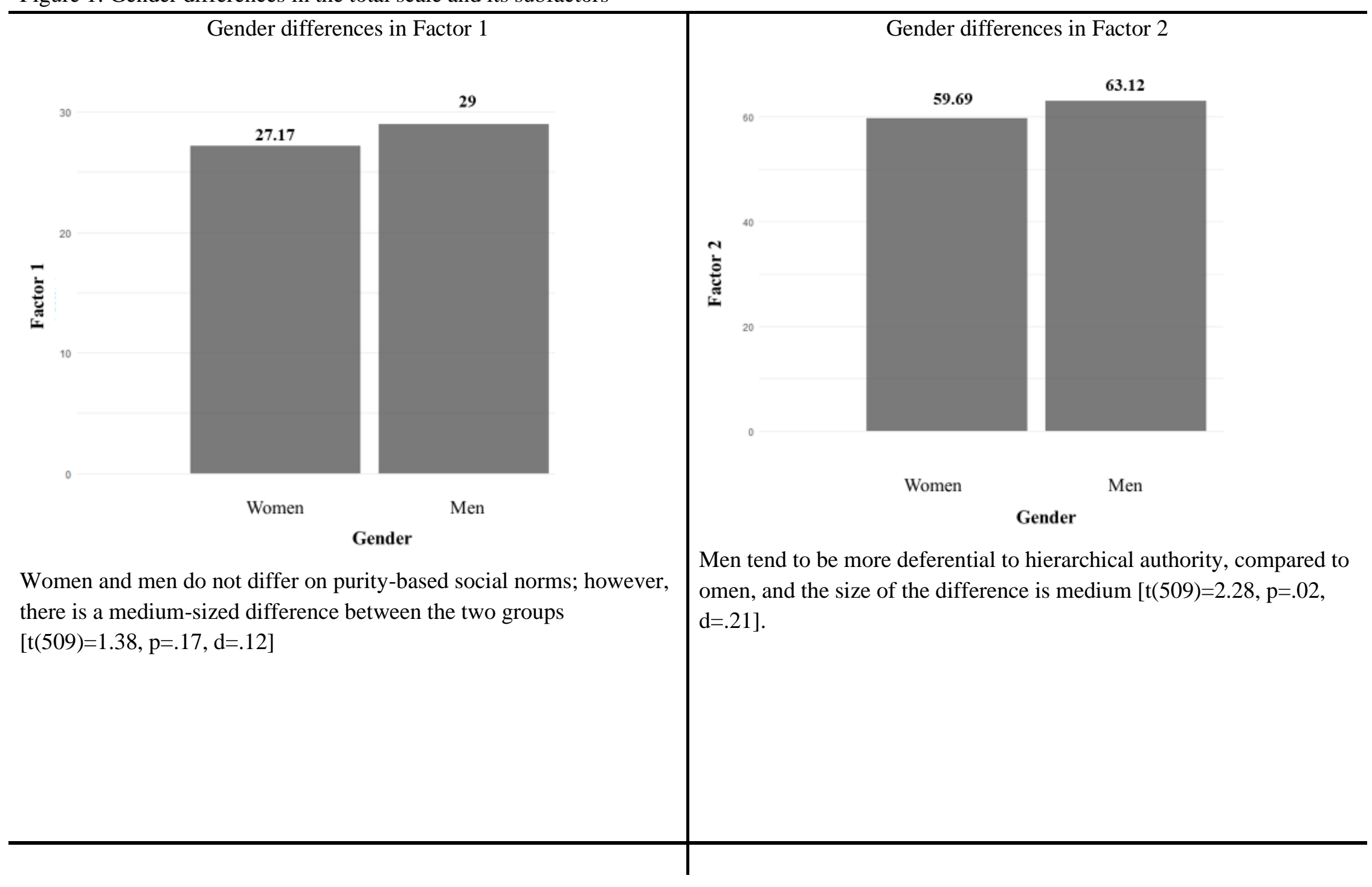




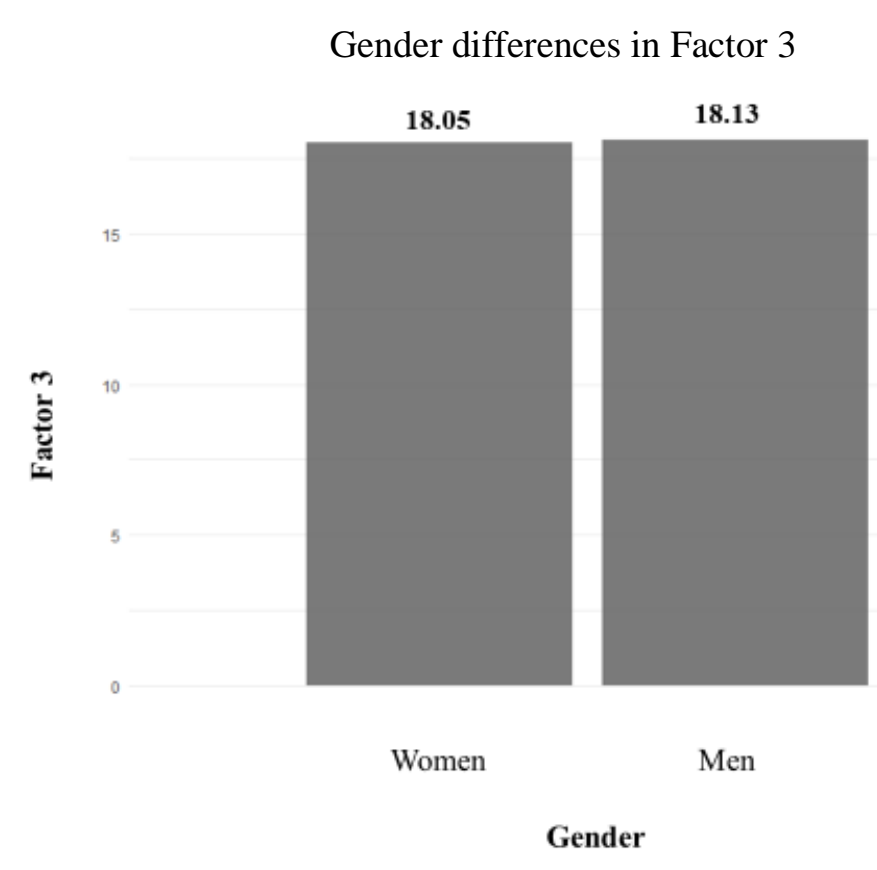

Men and women do not differ significantly on economic ideology; the difference is also negligence; $\mathrm{t}(509)=.20, \mathrm{p}=.84, \mathrm{~d}=.02$
Gender differences in the total scale

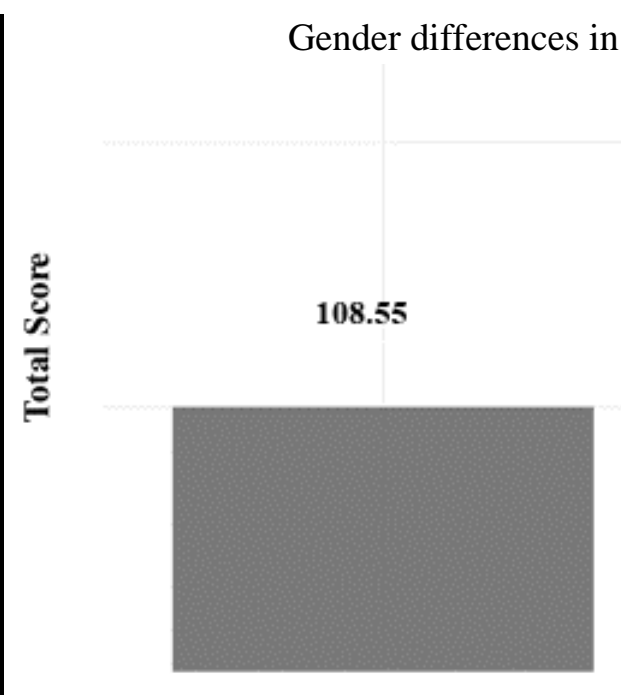

Women

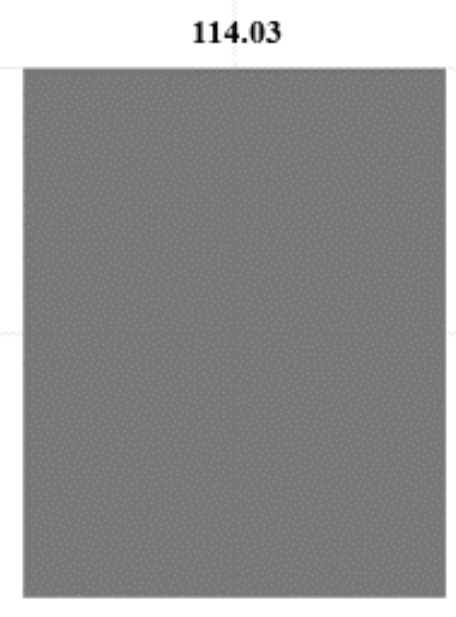

Men

\section{Gender}

Overall, there is a significant difference in political ideology, and the difference is comparatively large; $\mathrm{t}(509)=2.20, \mathrm{p}=.03, \mathrm{~d}=.20$. 
Table 1: Factor Loadings

\begin{tabular}{|c|c|c|c|}
\hline Item & Factor 1 & Factor 2 & Factor 3 \\
\hline 20. LGBTQ+ individuals should not be allowed to have children. & 0.78 & -0.01 & -0.02 \\
\hline 3. LGBTQ+ individuals should not have the right to marry & 0.74 & -0.03 & -0.04 \\
\hline $\begin{array}{l}\text { 10. I do not think those who identify as LGBTQ + deserve to be } \\
\text { treated with respect. }\end{array}$ & 0.71 & -0.06 & -0.01 \\
\hline 13. I do not think same sex marriages should be allowed. & 0.71 & 0.08 & -0.07 \\
\hline $\begin{array}{l}\text { 29. I think inter-caste marriages are frowned upon for a reason, and } \\
\text { therefore should be not be allowed. }\end{array}$ & 0.7 & 0.03 & 0 \\
\hline 7. I prefer not associating myself with LGBTQ+ individuals. & 0.67 & 0.12 & -0.04 \\
\hline $\begin{array}{l}\text { 25. I think giving away dowry at the time of a girl's wedding is not a } \\
\text { problem. }\end{array}$ & 0.66 & -0.02 & 0.03 \\
\hline $\begin{array}{l}\text { 40. I believe that sons and daughters have equal rights to parents' } \\
\text { property. }\end{array}$ & 0.67 & -0.2 & 0.12 \\
\hline $\begin{array}{l}\text { 2. I believe that everyone deserves an equal opportunity to enter fields } \\
\text { of their choosing, regardless of their social groups. }\end{array}$ & 0.64 & -0.21 & 0.23 \\
\hline $\begin{array}{l}\text { religious communities. } \\
\text { r I think we should }\end{array}$ & 0.63 & 0.06 & -0.04 \\
\hline $\begin{array}{l}\text { 9. I think we should not allow inter-state migration because the } \\
\text { migrants take away our jobs when they come here. }\end{array}$ & 0.51 & 0.23 & -0.05 \\
\hline not focus on appeasing them by reducing their taxes. & 0.49 & 0.17 & 0.21 \\
\hline $\begin{array}{l}\text { 41. I think we should censor movies and TV shows to uphold our } \\
\text { cultural values. }\end{array}$ & 0.47 & 0.36 & -0.22 \\
\hline $\begin{array}{l}\text { 11. I think dowry is equivalent to daughters' share of inheritance of } \\
\text { her parents' property. }\end{array}$ & $\mathbf{0 . 4 5}$ & 0.13 & -0.05 \\
\hline 36. We should always follow the values of our country. & 0.06 & 0.74 & -0.16 \\
\hline $\begin{array}{l}\text { 27. I think caste-based reservations in educational institutions is } \\
\text { increasing casteism. }\end{array}$ & -0.09 & 0.65 & 0.24 \\
\hline 18. Obedience to authority should be taught in school. & 0.05 & 0.66 & -0.03 \\
\hline $\begin{array}{l}\text { 48. I think it is necessary to stand up when the National Anthem plays } \\
\text { before a movie. } \\
\text { 19 I think the reason we have so many crimes hannening is because }\end{array}$ & -0.02 & 0.65 & -0.09 \\
\hline we are too lenient with our criminals. & -0.1 & 0.59 & 0.15 \\
\hline
\end{tabular}


17. I think some crimes should be given death penalty.

\begin{tabular}{rrr}
-0.17 & $\mathbf{0 . 5 6}$ & 0.36 \\
0.05 & $\mathbf{0 . 6 5}$ & -0.15 \\
0 & $\mathbf{0 . 5 4}$ & 0.05 \\
0.32 & $\mathbf{0 . 5 1}$ & -0.11 \\
-0.06 & $\mathbf{0 . 4 6}$ & 0.06 \\
0.11 & $\mathbf{0 . 4 8}$ & 0.03 \\
0.36 & $\mathbf{0 . 4 2}$ & -0.05 \\
0.27 & $\mathbf{0 . 4 4}$ & -0.11 \\
& & \\
0.28 & $\mathbf{0 . 4 1}$ & 0.14 \\
-0.05 & $\mathbf{0 . 4}$ & 0.12 \\
\hline
\end{tabular}

37. I think my country (India) is the best.

45. The law of the land should be obeyed, no matter what.

5. I think people should not abandon the religion they are born into.

26. I think reservations should strictly be based on economic grounds.

35. People nowadays do not appreciate our traditional values.

22. I think we should support our country's leader(s) no matter what.

23. I think a man and a woman should always try to make amends,

rather than getting divorced.

6. I don't think it is the duty of my country to take in refugees from

Bangladesh.

14. I think as a country we do not spend enough on national security.

42. It is the responsibility of the government to reduce the differences

in wealth between the poor and the rich. $\quad 0.29$

44. I think government should control prices of goods and services.

0.08

0.06

0.42

38. I think we should rehabilitate criminals, rather than punish them.

0.09

$-0.28$

0.41

28. Large industries should be under government control.

$-0.03$

0.24

0.38

34. I think we should have high taxes for luxury goods.

0.14

$-0.09$

0.31

\section{Removed Items}

8. The government should bail out traditional firms/industries that are going under.

\begin{tabular}{rrr}
-0.03 & -0.15 & -0.05 \\
0.08 & 0.09 & 0.15 \\
0.28 & 0.21 & -0.05 \\
0.29 & 0.16 & 0.16 \\
& & \\
-0.21 & -0.04 & -0.2 \\
& & \\
0.25 & -0.32 & -0.16 \\
0.24 & 0.05 & 0 \\
-0.01 & 0.14 & 0.29 \\
0.41 & 0.44 & -0.1 \\
\hline
\end{tabular}

16. I think all taxation is theft.

21. I think religious banning of meat is unfair.

31. It is justified to acquire private agricultural land for industrial purposes by the government.

32. The government should help business houses and industries succeed.

33. I think the government should not exempt tax for the rich.

39. Private enterprise is the solution to most economic problems.

0.41

$-0.08$

0.26

46. I do not think movies and TV shows should show obscene scenes. 
Table 2: Descriptive Statistics and Correlations with relevant constructs for Study 1

\begin{tabular}{|c|c|c|c|c|c|c|c|c|c|c|c|c|}
\hline & $N$ & $M$ & $S D$ & 1 & 2 & 3 & 4 & 5 & 6 & 7 & 8 & 9 \\
\hline 1. Age & 514 & 24.8 & 8.44 & 1 & & & & & & & & \\
\hline 2. Sex & 514 & & & $0.43^{* * * *}$ & 1 & & & & & & & \\
\hline 3. Norms & 514 & 27.86 & 14.61 & $0.10^{*}$ & 0.05 & 1 & & & & & & \\
\hline 4. Hierarchies & 514 & 64.7 & 17.46 & $0.16^{* * * *}$ & $0.09^{*}$ & $0.41^{* * * *}$ & 1 & & & & & \\
\hline 5. Economic Ideology & 514 & 18.07 & 4.65 & 0.02 & 0 & $0.10^{*}$ & 0.01 & 1 & & & & \\
\hline $\begin{array}{l}\text { 6. Self-Reported Awareness of } \\
\text { Issues }\end{array}$ & 514 & 4.82 & 1.44 & $0.21^{* * * *}$ & $0.32^{* * *}$ & -0.06 & -0.03 & -0.01 & 1 & & & \\
\hline $\begin{array}{l}\text { 7. Self-Reported Interest in } \\
\text { Politics }\end{array}$ & 514 & 4.49 & 1.81 & $0.18^{* * * *}$ & $0.30^{* * * *}$ & -0.07 & -0.08 & -0.05 & $0.62^{* * * *}$ & 1 & & \\
\hline $\begin{array}{l}\text { 8. Self-Reported Political } \\
\text { Ideology }\end{array}$ & 496 & 3.51 & 1.4 & $0.18^{* * * *}$ & $0.13^{* *}$ & $0.25^{* * *}$ & $0.47^{* * *}$ & $0.19^{* * * *}$ & 0.05 & 0.04 & 1 & \\
\hline $\begin{array}{l}\text { 9. Self-Reported Social } \\
\text { Ideology }\end{array}$ & 497 & 3.18 & 1.68 & $0.12^{* *}$ & 0 & $0.33^{* * *}$ & $0.49^{* * *}$ & $0.10^{*}$ & -0.04 & -0.05 & $0.61^{* * *}$ & 1 \\
\hline $\begin{array}{l}\text { 10. Self-Reported Economic } \\
\text { Ideology }\end{array}$ & 499 & 3.69 & 1.4 & $0.13^{* *}$ & $0.12^{* *}$ & $0.25^{* * *}$ & $0.34^{* * *}$ & $0.20^{* * * *}$ & $0.10^{*}$ & $0.10^{*}$ & $0.63^{* * *}$ & $0.43^{* * *}$ \\
\hline
\end{tabular}


Table 3: Descriptive Statistics and zero-order correlations for Study 2

\begin{tabular}{|c|c|c|c|c|c|c|c|c|c|c|c|c|c|c|c|}
\hline & $N$ & $M$ & $S D$ & 1 & 2 & 3 & 4 & 5 & 6 & 7 & 8 & 9 & 10 & 11 & 12 \\
\hline 1.Norms & & 151.38 & 241.29 & & & & & & & & & & & & \\
\hline 2. Hierarchy & & 199.5 & 145.99 & -0.11 & & & & & & & & & & & \\
\hline $\begin{array}{l}\text { 3. Economic } \\
\text { Ideology }\end{array}$ & & 184.75 & 109.35 & 0.24 & $0.33^{* * * *}$ & & & & & & & & & & \\
\hline $\begin{array}{l}\text { 4. Political } \\
\text { Ideology Scale }\end{array}$ & & 151.38 & 241.29 & $0.74^{* * *}$ & $0.87^{* * *}$ & $0.68^{* * *}$ & & & & & & & & & \\
\hline 5. Age & 380 & 26.6 & 9.42 & 0.04 & $0.16^{* *}$ & 0.03 & $0.15^{* *}$ & & & & & & & & \\
\hline $\begin{array}{l}\text { 6. Number of } \\
\text { children }\end{array}$ & 378 & 0.25 & 0.71 & -0.02 & $0.15^{\text {** }}$ & 0.03 & $0.13^{\text {*** }}$ & $0.69^{* * *}$ & & & & & & & \\
\hline $\begin{array}{l}\text { 7. Self-reported } \\
\text { socio-economic } \\
\text { level }\end{array}$ & 382 & 6.01 & 1.72 & -0.25 & 0.04 & $-0.10^{*}$ & -0.05 & $0.13^{* *}$ & 0.09 & & & & & & \\
\hline $\begin{array}{l}\text { 8. Economic level } \\
\text { based on family } \\
\text { income }\end{array}$ & 373 & 6.37 & 1.31 & 0.18 & -0.01 & 0.04 & 0.00 & 0.10 & 0.08 & $0.18^{* * *}$ & & & & & \\
\hline $\begin{array}{l}\text { 9. Political } \\
\text { Awareness }\end{array}$ & 372 & 5.95 & 1.52 & 0.07 & -0.01 & -0.07 & -0.07 & 0.03 & 0.06 & $0.14^{* *}$ & $0.25^{* * *}$ & & & & \\
\hline $\begin{array}{l}\text { 10. Interest in } \\
\text { Politics }\end{array}$ & 368 & 4.81 & 1.49 & 0.01 & 0.07 & -0.02 & 0.04 & $0.20^{* * *}$ & 0.06 & $0.12^{*}$ & $0.13^{* *}$ & $0.38^{* * * *}$ & & & \\
\hline $\begin{array}{l}\text { 11. Self-Rated } \\
\text { Political Ideology }\end{array}$ & 371 & 4.27 & 1.65 & -0.22 & $-0.21^{\text {**** }}$ & $-0.11^{*}$ & $-0.23^{* * *}$ & -0.01 & 0.04 & 0.10 & 0.07 & $0.36^{* * *}$ & $0.24^{* * *}$ & & \\
\hline $\begin{array}{l}\text { 12. Self-Rated } \\
\text { Ideology with } \\
\text { respect to Social } \\
\text { Issues }\end{array}$ & 370 & 3.43 & 1.33 & $-0.29^{*}$ & $0.20^{* * * *}$ & 0.08 & $0.18^{* *}$ & $0.15^{\text {** }}$ & $0.14^{* *}$ & -0.02 & -0.05 & 0.04 & -0.05 & $0.31^{* * *}$ & \\
\hline $\begin{array}{l}\text { 13. Self-Rated } \\
\text { Ideology with } \\
\text { respect to } \\
\text { Economic Issues }\end{array}$ & 370 & 3.51 & 1.37 & -0.24 & $0.27^{* * *}$ & $0.14^{*}$ & $0.27^{* * *}$ & $0.20^{* * *}$ & $0.13^{* *}$ & -0.06 & -0.04 & $-0.13^{*}$ & -0.07 & $0.13^{*}$ & $0.68^{* * *}$ \\
\hline
\end{tabular}


Table 4A: Fit Estimates based on confirmatory factor analyses 1 and 2.

\begin{tabular}{|c|c|c|c|c|c|c|}
\hline & \multicolumn{3}{|c|}{ CFA: Original Model } & \multicolumn{3}{|c|}{ CFA: Modified Model } \\
\hline & & Estimate & SE & & Estimate & SE \\
\hline \multirow[t]{14}{*}{ Norms } & $\mathrm{S} 20$ & 2.352 & 0.083 & S20 & 2.351 & 0.082 \\
\hline & S3 & 2.434 & 0.075 & S3 & 2.431 & 0.075 \\
\hline & S10 & 2.368 & 0.083 & S10 & 2.367 & 0.083 \\
\hline & S13 & 2.403 & 0.071 & S13 & 2.399 & 0.072 \\
\hline & S29 & 2.482 & 0.068 & S29 & 2.478 & 0.068 \\
\hline & S7 & 2.222 & 0.076 & S7 & 2.217 & 0.076 \\
\hline & S25 & 2.431 & 0.07 & S25 & 2.427 & 0.071 \\
\hline & S40R & 2.055 & 0.108 & S40R & 2.061 & 0.107 \\
\hline & $\mathrm{S} 2 \mathrm{R}$ & 2.24 & 0.094 & S2R & 2.243 & 0.093 \\
\hline & S24 & 2.431 & 0.073 & S24 & 2.431 & 0.073 \\
\hline & S9 & 2.186 & 0.071 & S9 & 2.181 & 0.071 \\
\hline & S41 & 1.957 & 0.077 & S41 & 1.939 & 0.078 \\
\hline & E47 & 2.21 & 0.067 & E47 & 2.205 & 0.068 \\
\hline & S11 & 2.176 & 0.081 & S11 & 2.171 & 0.081 \\
\hline \multirow[t]{15}{*}{ Hierarchy } & S36 & 0.66 & 0.121 & S36 & 0.562 & 0.123 \\
\hline & $\mathrm{S} 27$ & 0.158 & 0.145 & S27 & 0.073 & 0.146 \\
\hline & S18 & 1.091 & 0.119 & S18 & 1.002 & 0.122 \\
\hline & S48 & 0.761 & 0.141 & $\mathrm{~S} 48$ & \multirow{3}{*}{\multicolumn{2}{|c|}{$\begin{array}{l}\text { Removed based on } \\
\text { Modification Indices }\end{array}$}} \\
\hline & S19 & 0.272 & 0.141 & S19 & & \\
\hline & S17 & -0.189 & 0.161 & S17 & & \\
\hline & S37 & 0.855 & 0.113 & S37 & 0.759 & 0.116 \\
\hline & $\mathrm{S} 45$ & 0.466 & 0.123 & S45 & 0.386 & 0.124 \\
\hline & S5 & 1.994 & 0.096 & S5 & 1.934 & 0.099 \\
\hline & S26 & -0.212 & 0.153 & S26 & -0.281 & 0.152 \\
\hline & S35 & 0.672 & 0.117 & S35 & 0.598 & 0.117 \\
\hline & S14 & 0.966 & 0.114 & S14 & 0.921 & 0.114 \\
\hline & $\mathrm{S} 22$ & 2.448 & 0.089 & $\mathrm{~S} 22$ & 2.395 & 0.085 \\
\hline & $\mathrm{S} 23$ & 1.241 & 0.099 & $\mathrm{~S} 23$ & 1.182 & 0.101 \\
\hline & S6 & 1.547 & 0.111 & S6 & 1.52 & 0.111 \\
\hline \multirow[t]{5}{*}{$\begin{array}{l}\text { Economic } \\
\text { Ideology }\end{array}$} & E44 & 0.153 & 0.133 & E44 & 0.183 & 0.135 \\
\hline & E28R & 0.275 & 0.139 & E28R & 0.271 & 0.142 \\
\hline & $\mathrm{E} 42$ & -1.557 & 0.132 & $\mathrm{E} 42$ & -1.6 & 0.134 \\
\hline & E34 & 0.794 & 0.13 & E34 & 0.817 & 0.131 \\
\hline & S38R & -0.687 & 0.124 & S38R & -0.677 & 0.126 \\
\hline
\end{tabular}


Table 4B: Factor Intercorrelations

\begin{tabular}{llllll}
\hline & \multicolumn{2}{l}{ Model 1 (Original Model) } & & \multicolumn{2}{c}{ Model 2 (Modified Model) } \\
\cline { 2 - 3 } \cline { 5 - 6 } & Hierarchies & $\begin{array}{l}\text { Economic } \\
\text { Ideology }\end{array}$ & & Hierarchies & $\begin{array}{l}\text { Economic } \\
\text { Ideology }\end{array}$ \\
\hline Norms & 0.67 & -0.507 & & 0.71 & -0.51 \\
Hierarchies & & -0.72 & & -0.71 \\
\hline
\end{tabular}


Table 5A: Measurement Invariance

\begin{tabular}{|c|c|c|c|c|c|c|c|c|c|c|c|}
\hline Factor & Model & $\mathrm{df}$ & AIC & BIC & $\chi^{2}$ & $\Delta \chi^{2}$ & $\Delta \mathrm{df}$ & CFI & RMSEA & $\Delta \mathrm{CFI}$ & $\triangle \mathrm{RMSEA}$ \\
\hline \multirow{5}{*}{$\begin{array}{r}\text { Full } \\
\text { Model }\end{array}$} & Configural & 862 & 39732 & 40458 & 2149.9 & & & 0.829 & 0.096 & NA & NA \\
\hline & Loadings & 890 & 39753 & 40373 & 2226.7 & $76.826^{* * *}$ & 28 & 0.822 & 0.096 & 0.006 & 0 \\
\hline & Intercepts & 918 & 39721 & 40235 & 2250.6 & 23.919 & 28 & 0.823 & 0.095 & 0.001 & 0.002 \\
\hline & Residuals & 949 & 39816 & 40213 & 2408.1 & $157.456^{* * *}$ & 31 & 0.806 & 0.097 & 0.017 & 0.003 \\
\hline & Means & 952 & 39818 & 40204 & 2415.6 & 7.583 & 3 & 0.806 & 0.097 & 0.001 & 0 \\
\hline \multirow[t]{5}{*}{ Norms } & Configural & 154 & 17672 & 17993 & 385.06 & & & 0.956 & 0.095 & NA & NA \\
\hline & Loadings & 167 & 17676 & 17947 & 415.01 & $29.954^{* * *}$ & 13 & 0.952 & 0.094 & 0.003 & 0 \\
\hline & Intercepts & 180 & 17658 & 17879 & 422.49 & 7.472 & 13 & 0.953 & 0.09 & 0.001 & 0.004 \\
\hline & Residuals & 194 & 17741 & 17909 & 534.36 & $111.875^{* * *}$ & 14 & 0.935 & 0.102 & 0.019 & 0.013 \\
\hline & Means & 195 & 17740 & 17904 & 535 & 0.642 & 1 & 0.935 & 0.102 & 0 & 0 \\
\hline \multirow[t]{5}{*}{ Hierarchies } & Configural & 88 & 16040 & 16296 & 319.14 & & & 0.805 & 0.12 & NA & NA \\
\hline & Loadings & 98 & 16047 & 16264 & 346.71 & $27.568^{* * * *}$ & 10 & 0.786 & 0.12 & 0.019 & 0.00 \\
\hline & Intercepts & 108 & 16042 & 16220 & 361.2 & 14.491 & 10 & 0.782 & 0.116 & 0.005 & 0.004 \\
\hline & Residuals & 119 & 16052 & 16188 & 393.76 & $32.559^{* * * *}$ & 11 & 0.767 & 0.114 & 0.015 & 0.001 \\
\hline & Means & 120 & 16053 & 16185 & 396.69 & 2.928 & 1 & 0.765 & 0.114 & 0.002 & 0 \\
\hline \multirow{5}{*}{$\begin{array}{l}\text { Economic } \\
\text { Ideology }\end{array}$} & Configural & 10 & 7653.4 & 7770.8 & 24.519 & & & 0.892 & 0.089 & NA & NA \\
\hline & Loadings & 14 & 7647 & 7748.7 & 26.063 & 1.543 & 4 & 0.91 & 0.068 & 0.018 & 0.02 \\
\hline & Intercepts & 18 & 7644.1 & 7730.2 & 31.161 & 5.099 & 4 & 0.902 & 0.063 & 0.008 & 0.005 \\
\hline & Residuals & 23 & 7643.2 & 7709.8 & 40.335 & 9.174 & 5 & 0.871 & 0.064 & 0.031 & 0.001 \\
\hline & Means & 24 & 7641.9 & 7704.5 & 41.033 & 0.699 & 1 & 0.874 & 0.062 & 0.002 & 0.002 \\
\hline
\end{tabular}

Note. ${ }^{*} \mathrm{p}<.05 ;{ }^{* *} \mathrm{p}<.01 ;{ }^{* * *} \mathrm{p}<.001$ 
Table 5B: dMACS

\begin{tabular}{|c|c|c|c|c|c|c|c|c|}
\hline \multicolumn{3}{|c|}{ Norms } & \multicolumn{3}{|c|}{ Hierarchies } & \multicolumn{3}{|c|}{ Economic Ideology } \\
\hline Items & dMACS & $\Delta$ Means & Items & dMACS & $\Delta$ Means & Items & dMACS & $\Delta$ Means \\
\hline S20 & 0.05 & 0.13 & S36 & 0.11 & -0.15 & E44 & 0.10 & -0.08 \\
\hline S3 & 0.14 & 0.31 & $\mathrm{~S} 27$ & .40 & -.65 & E28R & 0.14 & -0.22 \\
\hline S10 & 0.17 & 0.22 & $\mathrm{~S} 18$ & 0.17 & -0.37 & E42 & 0.20 & -0.16 \\
\hline S13 & 0.13 & 0.10 & S37 & 0.13 & -0.16 & E34 & 0.04 & -0.02 \\
\hline S29 & 0.15 & 0.19 & $\mathrm{~S} 45$ & 0.23 & -0.45 & S38R & 0.21 & -0.41 \\
\hline S7 & 0.27 & -0.02 & S5 & 0.21 & 0.26 & & & \\
\hline $\mathrm{S} 25$ & 0.20 & 0.34 & S26 & 0.28 & -0.44 & & & \\
\hline S40R & 0.03 & -0.05 & $\mathrm{~S} 35$ & 0.21 & -0.34 & & & \\
\hline S2R & 0.12 & 0.22 & $\mathrm{~S} 14$ & 0.12 & -0.13 & & & \\
\hline $\mathrm{S} 24$ & 0.08 & 0.21 & $\mathrm{~S} 22$ & 0.33 & -0.28 & & & \\
\hline S9 & 0.09 & 0.21 & $\mathrm{~S} 23$ & 0.30 & -0.51 & & & \\
\hline S41 & 0.13 & 0.30 & S6 & 0.32 & -0.14 & & & \\
\hline E47 & 0.10 & 0.25 & & & & & & \\
\hline S11 & 0.17 & 0.36 & & & & & & \\
\hline Mean Difference & & 2.77 & Mean Difference & & -2.69 & Mean Difference & & -0.89 \\
\hline Difference in & & 87.89 & Difference in & & 16.66 & Difference in & & 0.22 \\
\hline Variance & & & Variance & & & Variance & & \\
\hline
\end{tabular}




\section{Printed Appendix}

Notes

1. A transfer of parental property from the bride's family during weddings. It is often a tool of gender-based violence and exploitation (e.g., Banerjee, 2014; Bhalotra et al., 2020).

2. We wanted to inspect whether refugees from different countries would be assessed differently. As all six items about refugees loaded on a single factor, this was collapsed and a single general item was formed, which loaded on the second factor. 